\title{
Electrochemically-Induced Reactions \\ of Hexafluorophosphate Anions with Water in Negative Ion Electrospray Mass Spectrometry of Undiluted Ionic Liquids
}

\author{
Yuchen Lu and Fred L. King \\ Department of Chemistry, West Virginia University, Morgantown, West Virginia, USA \\ Douglas C. Duckworth \\ Chemical Science Division, Oak Ridge National Laboratory, Oak Ridge, Tennessee, USA
}

\begin{abstract}
The influence of water on the observed gas-phase population of negative ions in electrospray mass spectrometry was studied for the undiluted ionic liquid 1,3-butyl-methyl-imidazolium hexafluorophosphate $\left(\mathrm{BMIM}^{+} \mathrm{PF}_{6}^{-}\right)$. During the electrospray process, electrolytic reduction of water enhances the production of tetrafluorophosphate $\left(\mathrm{F}_{4} \mathrm{PO}^{-}\right)$, which undergoes further reactions to produce difluorophosphate $\left(\mathrm{F}_{2} \mathrm{PO}_{2}^{-}\right)$anions. These anions are observed in addition to the pre-existing hexafluorophosphate anion. The apparent substitution of two fluorine atoms with one oxygen is attributed to a series of reactions initiated by hydrolysis of hexafluorophosphate. This hydrolysis reaction was enhanced by the addition of hydroxide, formed via the hydrolysis of water or through the addition of ammonium hydroxide. The formation of $\mathrm{F}_{\mathrm{x}} \mathrm{PO}_{\mathrm{y}}^{-}$was studied as a function of the electrospray current and solution flow rate. The mass spectral response shows a quantitative logarithmic relationship between $\Sigma \mathrm{F}_{\mathrm{x}} \mathrm{PO}_{\mathrm{y}}^{-}$signal intensities (adjusted for mole equivalents of $\mathrm{H}_{2} \mathrm{O}$ required) and the amount of water present, against which the water content could be rapidly assessed. Results were found to be comparable to Karl Fischer titration data. (J Am Soc Mass Spectrom 2006, 17, 939-944) (C) 2006 American Society for Mass Spectrometry
\end{abstract}

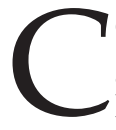
omposed entirely of organic cations and inorganic complex anions, room temperature ionic liquids (ILs) have attracted tremendous attention as novel solvents. The most commonly investigated cations are $\mathrm{N}, \mathrm{N}$-dialkylimidazolium, $\mathrm{N}$-alkylpyridinium, and tetra-alkyl-ammonium. Common anions are tetrafluoroborate $\left(\mathrm{BF}_{4}^{-}\right)$, hexafluorophosphate $\left(\mathrm{PF}_{6}^{-}\right)$, bis[(trifluoromethyl)sulfonate]amide $\left(\mathrm{TF}_{2} \mathrm{~N}^{-}\right)$, and trifluoroethanoate $\left(\mathrm{CF}_{3} \mathrm{CO}_{2}^{-}\right)$. These salts display unique properties in addition to being liquid at room-temperature. These include negligible vapor pressure, wide electrochemical windows, and high ionic conductivity. As an alternative to aqueous or organic solvents, ILs are thought to hold much promise for green chemistry applications. As a new solvent system, ILs are being investigated in a variety of applications such as polymer synthesis [1-3], catalytic processes [4, 5], electrochemical reactions [6], liquid-liquid extractions [7], and

Published online May 15, 2006

Address reprint requests to Dr. D. C. Duckworth, Chemical Science Division, Oak Ridge National Laboratory, MS-6375, P.O. Box 2008, Oak Ridge, TN 37830, USA. E-mail: duckworthdc@ornl.gov as a vacuum compatible matrix for matrix-assisted laser desorption/ionization [8-13].

Impurities and their effects on the properties of the ILs have been the subject of several studies [6,14-16]. Because ILs often absorb water, the effect of water on electrochemical properties has been studied [6, 14]. Research on the solubility of water in ILs is very important, particularly when the ILs are used with water sensitive materials and reactions. Depending on the choice of anions, water solubility varies [14]. For example, ILs composed of $\mathrm{PF}_{6}^{-}$anions are not watermiscible, yet $\mathrm{Cl}^{-}$based ILs are water-miscible. Despite the immiscibility of $\mathrm{PF}_{6}^{-}$based ILs, water is often absorbed at concentrations as high as $16 \%(\mathrm{wt} / \mathrm{wt})$ [14]. Studies of water-contaminated 1-butyl-3-methylimidazolium hexafluorophosphate $\left(\mathrm{BMIM}^{+} \mathrm{PF}_{6}^{-}\right)$ionic liquids suggest that the water/IL system is not homogenous but is instead a "nano-structured", bi-phasic solution [6]. The presence of water in such water-immiscible ILs was found to affect electrochemical characteristics and increase ion diffusion rates [6, 14-16].

Electrospray mass spectrometry (ES-MS) has been widely used to transfer ions from the liquid phase into the gas-phase for MS analysis. It has extended the range 
of MS applications to high polarity, high mass, and highly labile molecules. Alfassi et al. developed a method using ES-MS to quantify the hydrophobic IL solubilities in water [17]. Acceptable ES-MS detection of minor analyte species, such as $\left[\mathrm{Ru}\left(\eta^{6}-p\right.\right.$-cymene $)$ $\left(\eta^{2}\right.$-triphos $\left.) \mathrm{Cl}\right]^{+}$, within an IL matrix has been performed following a $10^{5}: 1$ dilution with methanol [18]. Similarly, negative ion ES-MS has proven useful for the detection of negative species such as the anionic catalyst $\left[\mathrm{Ru}(\mathrm{CO})_{2} \mathrm{I}_{2}\right]^{-}$and $\mathrm{Cl}^{-}$[18]. ES-MS analysis of tetrabutylammonium ions and neutral ferrocene ions in neat (undiluted) ILs has been investigated and was found to have sensitivity for these dissolved analytes comparable to the diluted ILs $[19,20]$. The nonvolatile nature of ILs has not proven to be a limitation in the generation of these ions via electrospray.

In our laboratory, negative ion ES-MS of undiluted $\mathrm{BMIM}^{+} \mathrm{PF}_{6}^{-}$ILs is observed to generate water-related product anions from $\mathrm{PF}_{6}^{-}$with the general formula $\mathrm{F}_{\mathrm{x}} \mathrm{PO}_{\mathrm{y}}^{-}$(i.e., $\mathrm{F}_{4} \mathrm{PO}^{-}$and $\mathrm{F}_{2} \mathrm{PO}_{2}^{-}$). This chemistry is thought to be driven by electrochemical processes within the ES emitter. The study of this chemistry is presented here, and the correlation between water content and $\mathrm{F}_{\mathrm{x}} \mathrm{PO}_{\mathrm{y}}^{-}$response is characterized.

\section{Experimental}

1,3-butyl-methyl-imidazolium hexafluorophosphate $\left(\mathrm{BMIM}^{+} \mathrm{PF}_{6}^{-}\right)$and 1,3-ethyl-methyl-imidazolium tetrafluoroborate $\left(\mathrm{EMIM}^{+} \mathrm{BF}_{4}^{-}\right.$) (Sigma-Aldrich, St. Louis, $\mathrm{MO}$ ), were vacuum-dried for $48 \mathrm{~h}$ and stored in a nitrogen filled desiccator. Biphasic water $/ \mathrm{BMIM}^{+} \mathrm{PF}_{6}^{-}$ mixtures formed when deionized water $(>18 \mathrm{M} \Omega \cdot \mathrm{cm}$, MilliQ, Billerica, MA) was spiked into the ILs. Homogenous solutions were obtained by ultra-sonication for $20 \mathrm{~min}$. Water concentrations reported in this study were calculated as follows. Karl Fischer titration (Brinkmann KF-652, Herisan, Switzerland) was used to establish the residual percent water in samples that were vacuum dried. If water was spiked into a sample, the weight of additional water was summed with that from the Karl Fischer determined "blank" to calculate the total water content.

Electrospray mass spectra were obtained with a Thermo Electron PolarisQ ion-trap mass spectrometer (Austin, TX) modified with the addition of a Thermo Electron Deca electrospray ion source. The ion optical system between the ion source and the mass analyzer is composed of two ion guides and an ion gating lens. The ion gating lens is a disk electrode with a $0.8 \mathrm{~mm}$ orifice that is positioned between quadrupole and octopole ion guides. Both ion guides operate at the same rf frequency, rf amplitude, and dc floating voltage, and are driven by a custom-built RF power supply [21]. The relative ion current was measured at the ion transfer tube by an electrometer (Orteck 710, Oak Ridge, TN). It should be noted that the high voltage emitter was operated without an upstream grounding point. Due to the high conductivity of ILs, (about 1000 times larger than conventional volatile solvents), grounding the injection line through the insertion of an ammeter decreased the spray voltage at the emitter tip, and disrupted the electrospray process.

An Oxford dual track syringe pump (AH55-2122, Holliston, MA) was used to continuously inject samples from a $250 \mu \mathrm{L}$ syringe (Hamilton, Reno, NV) at a constant flow rate of $0.3 \mu \mathrm{l} / \mathrm{min}$ unless otherwise noted. A $1 \mathrm{~m}$ PEEK tube with $125 \mu \mathrm{m}$ internal diameter (i.d.) connected the syringe and the emitter. The $125 \mu \mathrm{m}$ i.d. tubing was used to maintain a low backpressure for the viscous ILs. For the same purpose, PEEK unions (No. P-742, Upchurch Scientific, Oak Harbor, WA) with 250 $\mu \mathrm{m}$ i.d. were used. A $6 \mathrm{~cm}$ long stainless steel emitter with $100 \mu \mathrm{m}$ i.d. and $500 \mu \mathrm{m}$ o.d. was used in conjunction with a stainless steel union to which the spray voltage was applied. A Tennelec/Oxford dual-polarity 0-5 kV power supply (TC950A, Oak Ridge, TN) was used to provide the negative $3-5 \mathrm{kV}$ emitter potential.

\section{Results and Discussion}

To perform the initial characterization of electrospray mass spectrometry of undiluted ion liquids containing water, $\mathrm{BMIM}^{+} \mathrm{PF}_{6}^{-}$was spiked with 0 to $6 \%$ (wt/wt) of water, and conventional Karl Fischer titration was used to measure the water content. The samples were then studied by negative ion ES-MS as a function of voltage, flow rate, and water content.

\section{Mass Spectral Characterization}

It is known that electrochemical processes at the emitter surface can influence the abundance and identity of gas-phase ions in ES-MS [22, 23], with the degree of redox chemistry occurring being a function of both reaction time at the emitter surface and the spray current. To explore this, the emitter voltage was increased to increase spray current and the flow rate was reduced to increase redox efficiency to determine their effect of these parameters on gas-phase ion abundances of $\mathrm{F}_{\mathrm{x}} \mathrm{PO}_{\mathrm{y}}^{-}$.

Negative ion electrospray mass spectra of $\mathrm{BMIM}^{+} \mathrm{PF}_{6}^{-}$containing $0.24 \% \mathrm{H}_{2} \mathrm{O}$ are shown in Figure 1 for different emitter voltages. Injection flow rate was held constant at $0.3 \mu \mathrm{l} / \mathrm{min}$. Operating at a threshold voltage for ion production ( $3.0 \mathrm{kV}$ in Figure 1a), only pre-formed $\mathrm{PF}_{6}^{-}$ions are observed. The relative ion current $\left(i_{R C}\right)$ measured at the transfer tube was $0.31 \mu \mathrm{A}$. When the spray voltage was increased to $3.7 \mathrm{kV}$ and 5.0 $\mathrm{kV}$ (Figure $1 \mathrm{~b}$ and $\mathrm{c}$ ), the $i_{R C}$ increased to 0.90 and 2.02 $\mu \mathrm{A}$, respectively, with a corresponding increase in $\mathrm{F}_{\mathrm{x}} \mathrm{PO}_{\mathrm{y}}^{-}$anion intensities increased and a decrease in $\mathrm{PF}_{6}^{-}$ intensity. Anions $\mathrm{F}_{4} \mathrm{PO}^{-}$and $\mathrm{F}_{2} \mathrm{PO}_{2}^{-}$are the primary product ions observed along with $\mathrm{HPO}_{3}^{-}$and other less abundant ions whose identity could not be confirmed.

The effect of current on product ion distribution is not surprising because the electrospray ionization 


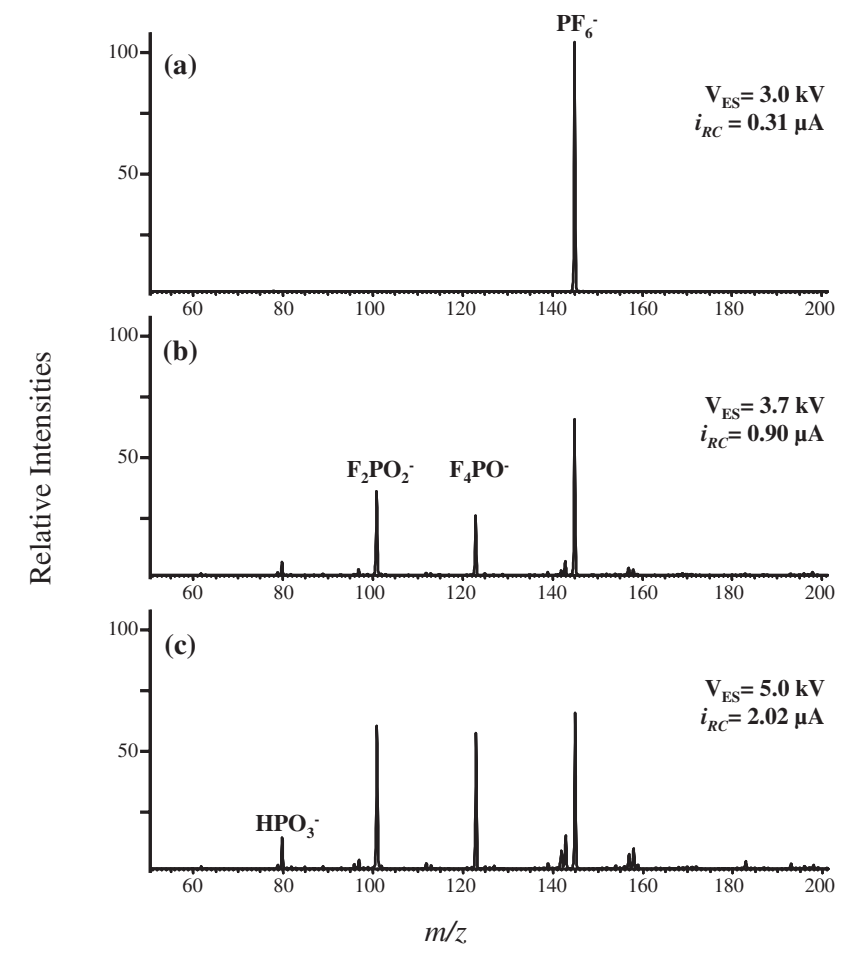

Figure 1. Negative ion ES-MS of $\mathrm{BMIM}^{+} \mathrm{PF}_{6}^{-}$at (a) $3.0 \mathrm{kV}$, (b) 3.7 $\mathrm{kV}$, and (c) $5.0 \mathrm{kV}$, each normalized to (a). Water content and flow rate were held constant at $0.24 \%(\mathrm{wt} / \mathrm{wt}$ ) and $0.3 \mu \mathrm{l} / \mathrm{min}$, respectively.

process is a controlled-current electrolytic process [22, 23]. Increases in emitter potential affect the magnitude of the redox current at the emitter surface. The extent of the reaction, and therefore $\mathrm{F}_{\mathrm{x}} \mathrm{PO}_{\mathrm{y}}^{-}$abundances, increases with the magnitude of ES current. As will be shown later, higher spray voltage $V_{E S}$ (resulting in higher emitter current) can be used to improve the sensitivity of water concentration determination.

Studies have shown that tetrafluorophosphate $\left(\mathrm{F}_{4} \mathrm{PO}^{-}\right)$, difluorophosphate $\left(\mathrm{F}_{2} \mathrm{PO}_{2}^{-}\right)$, and metaphosphate $\left(\mathrm{HPO}_{3}^{-}\right)$complex ions can be formed in battery cells from reactions initiated by the hydrolysis reaction of $\mathrm{PF}_{6}^{-}$[24-28]. The reactions are not simple consecutive processes. The decomposition of $\mathrm{PF}_{6}^{-}$starts with the formation of $\mathrm{F}_{3} \mathrm{PO}$ through the reaction of $\mathrm{PF}_{6}^{-}$with $\mathrm{H}_{2} \mathrm{O}$,

$$
\mathrm{PF}_{6}^{-}+\mathrm{H}_{2} \mathrm{O} \leftrightarrow \mathrm{F}_{3} \mathrm{PO}+2 \mathrm{H}^{+}+3 \mathrm{~F}^{-}
$$

and $\mathrm{F}_{3} \mathrm{PO}$ readily adds $\mathrm{F}^{-}$to form the $\mathrm{F}_{4} \mathrm{PO}^{-}$anion [25]:

$$
\mathrm{F}_{3} \mathrm{PO}+\mathrm{F}^{-} \rightarrow \mathrm{F}_{4} \mathrm{PO}^{-}
$$

Electrolytic hydrolysis of water during the electrospray process produces hydroxide ions as shown,

$$
2 \mathrm{H}_{2} \mathrm{O}+2 \mathrm{e}^{-} \rightarrow \mathrm{H}_{2}+2 \mathrm{OH}^{-}
$$

which neutralize the hydrofluoric acid produced in reaction $(\mathbf{1})$,

$$
2 \mathrm{OH}^{-}+2 \mathrm{HF} \rightarrow 2 \mathrm{H}_{2} \mathrm{O}+2 \mathrm{~F}^{-}
$$

assisting the decomposition of $\mathrm{PF}_{6}^{-}$according to Le Chatelier's principle. The net reaction of the $\mathrm{PF}_{6}^{-}$with water [reactions (1) to (4)] is

$$
\mathrm{PF}_{6}^{-}+\mathrm{H}_{2} \mathrm{O}+2 \mathrm{e}^{-} \rightarrow \mathrm{F}_{4} \mathrm{PO}^{-}+\mathrm{H}_{2}+2 \mathrm{~F}^{-}
$$

The role of hydroxide ions in the hydrolysis reactions was tested by ES-MS analysis of $\mathrm{BMIM}^{+} \mathrm{PF}_{6}^{-}$samples that were spiked with water and ammonium hydroxide. Figure 2 shows the mass spectrometric response to varying concentrations of $\mathrm{OH}^{-}$. Water content $(2.03 \%$ $\mathrm{wt} / \mathrm{wt})$ and the electrospray voltage $(3.7 \mathrm{kV})$ were held constant. The spectrum shown in Figure $2 \mathrm{a}$ was obtained before the addition of hydroxide ions. $\mathrm{PF}_{6}^{-}$is the dominant species and a relatively small fraction of fluorophosphates was transformed to $\mathrm{F}_{\mathrm{x}} \mathrm{PO}_{\mathrm{y}}^{-}$. As the concentration of $\mathrm{OH}^{-}$was increased [up to $0.16 \%$ (wt/wt)], $\mathrm{F}_{\mathrm{x}} \mathrm{PO}_{\mathrm{y}}^{-}$products became more abundant with the dominant species in mass spectra being $\mathrm{F}_{2} \mathrm{PO}_{2}^{-}$at the highest hydroxide concentration.

Difluorophosphate anion formation has been observed by others who reported that $\mathrm{F}_{4} \mathrm{PO}^{-}$anion undergoes the exothermic disproportionation reaction $\left(\Delta \mathrm{H}=-76 \mathrm{kcal} \cdot \mathrm{mol}^{-1}\right)[24,25]$,

$$
2 \mathrm{~F}_{4} \mathrm{PO}^{-} \rightarrow \mathrm{PF}_{6}^{-}+\mathrm{F}_{2} \mathrm{PO}_{2}^{-}
$$
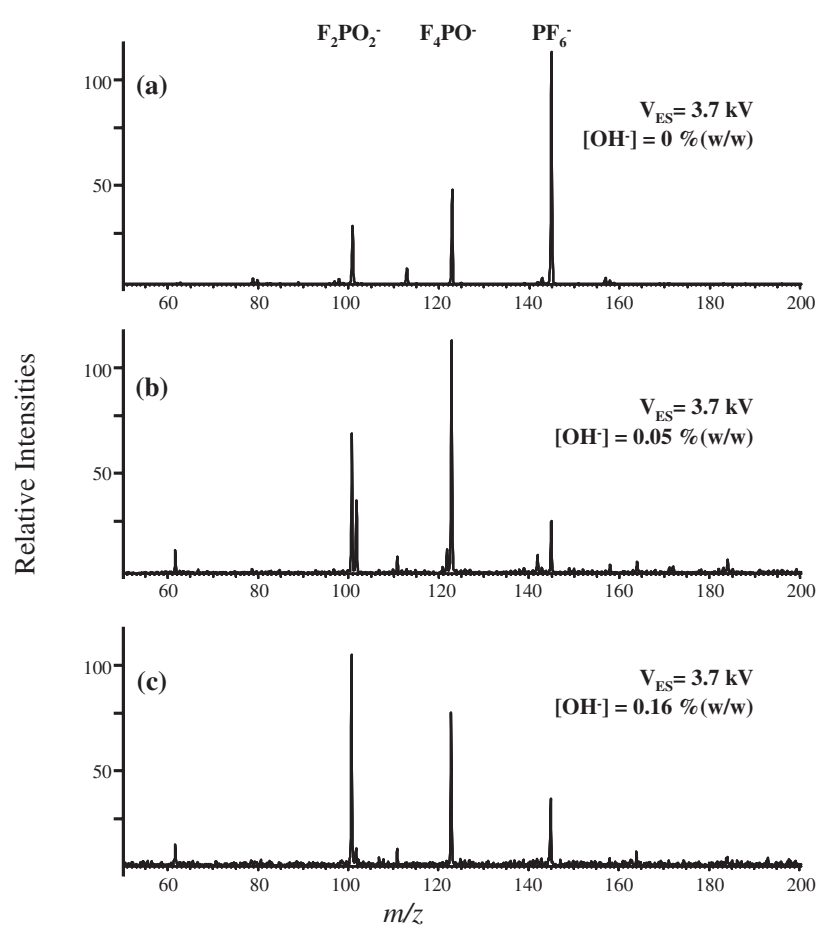

Figure 2. Negative ion ES-MS of $\mathrm{BMIM}^{+} \mathrm{PF}_{6}^{-}$spiked with $\mathrm{NH}_{4} \mathrm{OH}$ with $\left[\mathrm{OH}^{-}\right]$at (a) $0 \%(\mathrm{wt} / \mathrm{wt}),(\mathbf{b}) 0.05 \%(\mathrm{wt} / \mathrm{wt})$, and (c) $0.16 \%$ (wt/wt), each normalized to (a). Water content, electrospray voltage, and flow rate were held constant at $2.03 \%(\mathrm{wt} / \mathrm{wt}), 3.7 \mathrm{KV}$, and $0.3 \mu \mathrm{l} / \mathrm{min}$, respectively. 


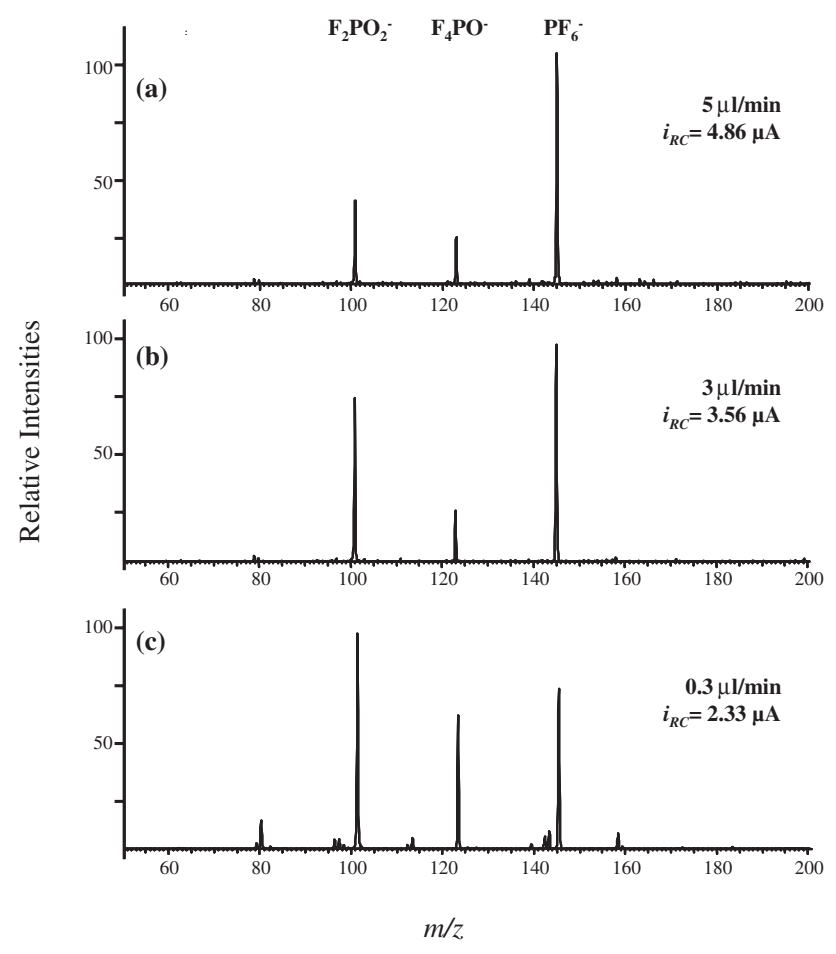

Figure 3. Negative ion ES-MS of $\mathrm{BMIM}^{+} \mathrm{PF}_{6}^{-}$at various flow rates, (a) $5 \mu \mathrm{l} / \mathrm{min}$, (b) $3 \mu \mathrm{l} / \mathrm{min}$, and (c) $0.3 \mu \mathrm{l} / \mathrm{min}$, each normalized to (a). Water content and electrospray voltage were held constant at $3.43 \%(\mathrm{wt} / \mathrm{wt})$ and $5.0 \mathrm{kV}$, respectively.

As the concentration of $\mathrm{F}_{4} \mathrm{PO}^{-}$increases, reaction (6) becomes kinetically favored. The amount of $\mathrm{F}_{4} \mathrm{PO}^{-}$anions decreases due to the disproportion reaction, and the abundance of $\mathrm{F}_{2} \mathrm{PO}_{2}^{-}$increases. Other negative ions of low abundance (e.g., $\mathrm{PO}_{3}^{-}, \mathrm{HPO}_{3}^{-}, \mathrm{H}_{2} \mathrm{PO}_{4}^{-}$in Figures 1, 2, 3, and 4) were also observed in ES-MS, but their origin and role in $\mathrm{PF}_{6}^{-}$reactions cannot be confirmed due to their low abundance and poor correlation with experimental variables.

The mass spectra shown in Figure 3 demonstrate the effect of solution flow rate on multifluorophosphate anion formation. $\mathrm{BMIM}^{+} \mathrm{PF}_{6}^{-}$solution was injected through the emitter at flow rates of $0.3,3$, and $5 \mu \mathrm{l} / \mathrm{min}$ with a constant emitter voltage of $5.0 \mathrm{kV}$. The degree of $\mathrm{PF}_{6}^{-}$hydrolysis is inversely proportional to flow rate. This is consistent with an electrochemically-induced reaction at the electrospray emitter that proceeds as a function of the interaction time of water at emitter surface. The reduction in $\mathrm{i}_{R C}$ primarily reflects the lowered mass throughput at low flow rates because $i_{R C}$ reflects the oxidation current for all ions arriving at the ion transfer line (including $\mathrm{PF}_{6}^{-}$) and is not a direct indication of the hydrolysis process alone. More IL and water mass is supplied at the higher flow rate, but the formation of hydrolysis products was low, presumably due to diffusion rate limitations.

\section{Effect of Water Content on $\mathrm{F}_{x} \mathrm{PO}_{y}^{-}$Response}

Karl Fischer titration results indicated that the "pure" vacuum-dried $\mathrm{BMIM}^{+} \mathrm{PF}_{6}^{-}$retains $0.24 \%$ (wt/wt) resid- ual water, demonstrating the difficulty in removing water from even water-immiscible ionic liquids. Incrementally increasing the electrospray voltage from 0 to 5 $\mathrm{kV}$ resulted in threshold voltages $\left(\mathrm{V}_{\mathrm{T}}\right)$ - the voltage at which gas-phase ions are generated-that are proportional to water content. The lowest threshold value of spray voltage was $3.0 \mathrm{kV}$ for the IL sample with the smallest amount of water. $\mathrm{V}_{\mathrm{T}}$ increased with water content up to $3.3 \mathrm{kV}$ for $1.4 \%$ water, reaching a plateau at $2 \%$.

Figure 4 shows ES mass spectra of three $\mathrm{BMIM}^{+} \mathrm{PF}_{6}^{-}$ samples with different water contents electrosprayed at an emitter voltage of $5.0 \mathrm{kV}$ and a flow rate of 0.3 $\mu \mathrm{l} / \mathrm{min}$. The gas-phase abundances of the $\mathrm{F}_{\mathrm{x}} \mathrm{PO}_{\mathrm{y}}^{-}$ions relative to $\mathrm{PF}_{6}^{-}$increase with water content. Since water content is directly related to the abundance of $\mathrm{F}_{\mathrm{x}} \mathrm{PO}_{\mathrm{y}}^{-}$ ions, these can provide a convenient method to quantify the water content of undiluted ILs using electrospray mass spectrometry.

In Figure 5, two calibration curves are shown that were generated using emitter voltages of $3.6 \mathrm{kV}\left(R^{2}=\right.$ $0.96)$ and $4.6 \mathrm{kV}\left(R^{2}=0.98\right)$. The anions $\mathrm{F}_{4} \mathrm{PO}^{-}$and $\mathrm{F}_{2} \mathrm{PO}_{2}^{-}$were plotted as function of weight concentration of water and normalized to the total ion signal measured in each scan. A weighting factor of two was used for $\mathrm{F}_{2} \mathrm{PO}_{2}^{-}$to reflect the number of water equivalents involved in $\mathrm{F}_{2} \mathrm{PO}_{2}^{-}$production. These demonstrate an empirically-determined logarithmic relationship be-
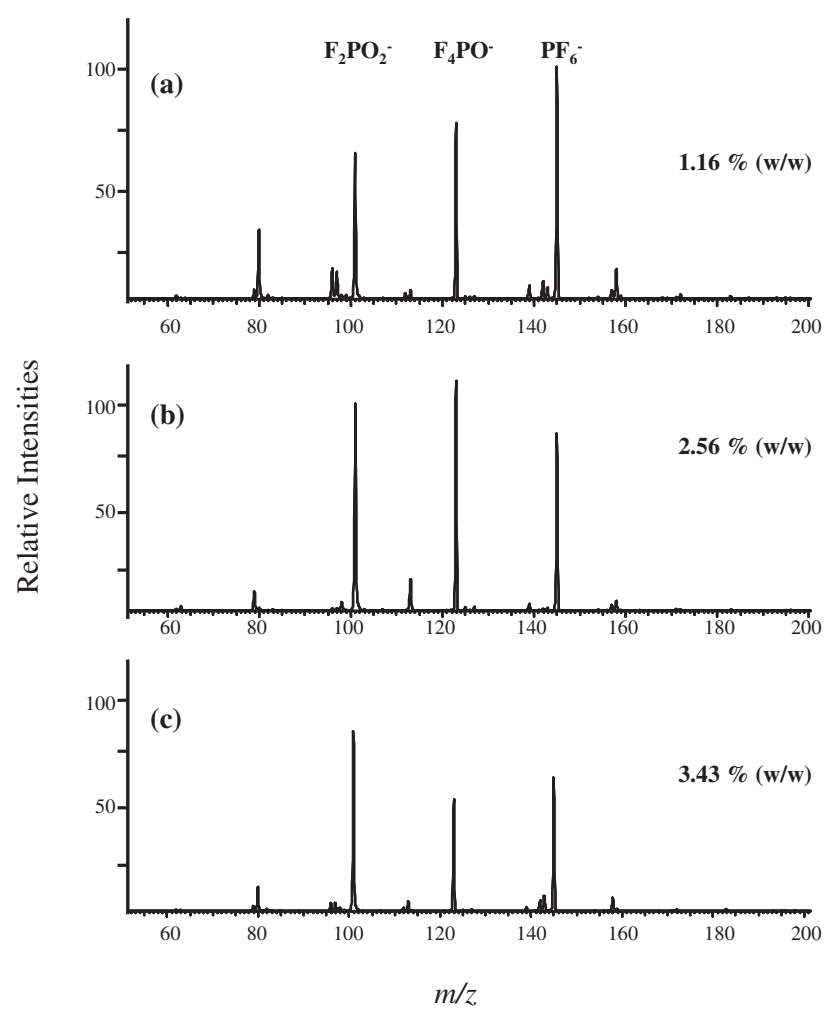

Figure 4. Negative ion ES-MS of $\mathrm{BMIM}^{+} \mathrm{PF}_{6}^{-}$at various water contents, (a) $1.16 \%(\mathrm{wt} / \mathrm{wt})$, (b) $2.56 \%(\mathrm{wt} / \mathrm{wt}$ ), and (c) $3.43 \%$ (wt/wt), each normalized to (a). Flow rate and electrospray voltage were held constant at $0.3 \mu \mathrm{l} / \mathrm{min}$ and $5.0 \mathrm{kV}$, respectively. 


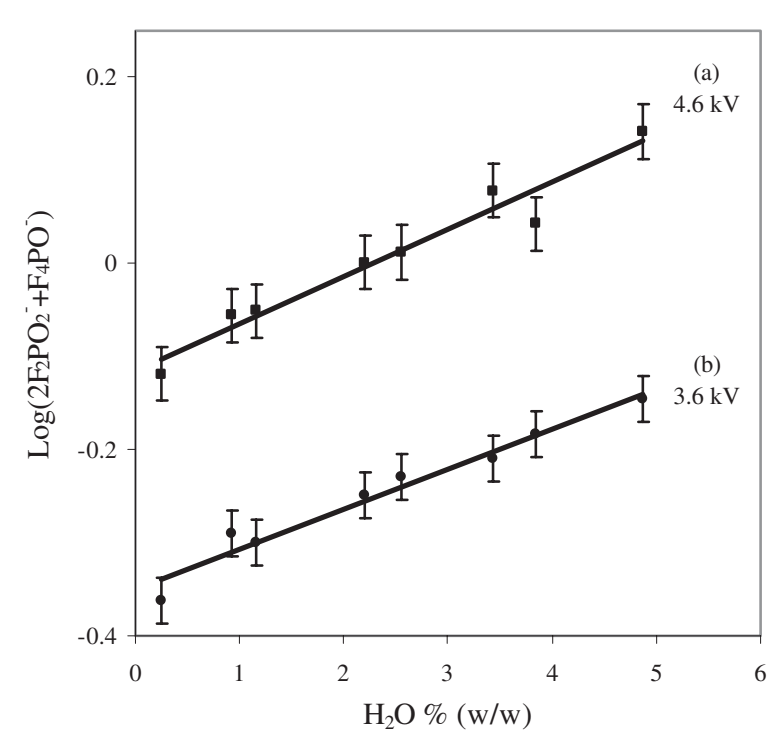

Figure 5. Relationship between extent of $\mathrm{PF}_{6}^{-} / \mathrm{H}_{2} \mathrm{O}$ reaction and water content for $\mathrm{BMIM}^{+} \mathrm{PF}_{6}^{-}$ES-MS at $3.6 \mathrm{kV}$ and $4.6 \mathrm{kV}$ and at flow rate of $0.3 \mu \mathrm{l} / \mathrm{min}$. The response of the fluorophosphates were weighted for mole equivalents of water required and the sum was normalized to the total ion current in each scan.

tween water content, as determined by Karl Fischer titration, and the sum $\left(\mathrm{F}_{4} \mathrm{PO}^{-}+2 \mathrm{~F}_{2} \mathrm{PO}_{2}^{-}\right)$normalized to total ion current. The nonlinear relationship with respect to water content is thought to be due to the relative and unknown rates of the pseudo-first-order reaction in eq 5 and the second-order disproportionation reaction (eq 6). Because the reaction rate constants are not known, the use of summed intensities of the multifluorophosphate ions is thought to be more accurate and straightforward.

The results of three measurements of $\mathrm{BMIM}^{+} \mathrm{PF}_{6}^{-}$ were averaged for each calibrant solution, ranging from $\sim 0.24 \%$ (wt $/ \mathrm{wt}$ ) to $\sim 6 \%$ (wt/wt) water. Consistent with redox current considerations, analytical sensitivity was higher at the $4.6 \mathrm{kV}$ emitter voltage. The slopes of two curves are 0.063 and 0.108 , resulting in a 1.7-fold enhancement in sensitivity at the higher emitter voltage.

The unspiked vacuum-dried sample retained a water content of $0.24 \%(\mathrm{wt} / \mathrm{wt})$. More vigorous cleaning procedures were not attempted. Because of the difficulty in removing the water residue from the $\mathrm{IL}$, lower water concentrations could not be evaluated and the dynamic range of the measurement was limited. The dynamic range of the method is bounded by water-solubility at the upper concentration limit and sample dehydration methods at the lower concentration limit.

The response curve shown in Figure $5 \mathrm{a}(4.6 \mathrm{kV})$ was used to quantify water content in two $\mathrm{BMIM}^{+} \mathrm{PF}_{6}^{-}$ samples. After spiking, the resulting water contents were calculated to be $0.92 \%(\mathrm{wt} / \mathrm{wt})$ and $1.16 \%(\mathrm{wt} /$ $w t)$. The results based on ES-MS measurements were $0.94 \%(\mathrm{wt} / \mathrm{wt})$ and $1.23 \%(\mathrm{wt} / \mathrm{wt})$ with relative standard deviations (RSD) of 7 and $12 \%$, respectively. Karl
Fischer titration results for the same samples were $0.92 \%$ and $1.04 \%$ with RSD of 13 and $8 \%$, respectively. The relative error of the measurement was less than $10 \%$, and accuracy and precision are comparable to the conventional Karl Fischer titration results, suggesting that negative ion ES-MS can provide an approach for the direct determination of water content for ionic liquids containing the $\mathrm{PF}_{6}^{-}$anion.

\section{Conclusions}

To most efficiently detect analytes or impurities within ionic liquids, electrochemical phenomenon favoring their formation must be considered. In the case of negative ion ES-MS of $\mathrm{PF}_{6}^{-}$-based ILs, the reactions of water with $\mathrm{PF}_{6}^{-}$results in the formation of multifluorophosphate $\left(\mathrm{F}_{x} \mathrm{PO}_{\mathrm{y}}^{-}\right)$ions. The substitution reaction that follows from the hydrolysis reaction of water with $\mathrm{PF}_{6}^{-}$ to generate $\mathrm{F}_{x} \mathrm{PO}_{y}^{-}$species during the electrospray process is consistent with known electrochemical reactions, and parametric studies of flow rate and electrospray current support this conclusion.

The $\mathrm{F}_{x} \mathrm{PO}_{\mathrm{y}}^{-}$products of the electrochemical reactions reported here provide an indicator of the water content in water-immiscible $\mathrm{BMIM}^{+} \mathrm{PF}_{6}^{-}$. The dependence on other residual solvents, dissolved contaminant species, and their concentrations on negative ion ES-MS will require further study, but the use of negative ion ES-MS for indirect measurement of water content in undiluted ILs can provide a rapid assessment of IL purity.

Initial studies indicate that similar product ions are obtained in ES-MS of $\mathrm{EMIM}^{+} \mathrm{BF}_{4}^{-}$. The electrochemically induced species $\mathrm{F}_{2} \mathrm{BO}^{-}$and $\mathrm{BO}_{2}^{-}$were observed when neat $\mathrm{BF}_{4}^{-}$based ILs were electrosprayed. The hydrolysis of $\mathrm{BF}_{4}^{-}$is thought to occur in an analogous manner to $\mathrm{PF}_{6}^{-}$and is a matter of ongoing chemical investigations.

\section{Acknowledgments}

The authors are indebted to Glen Jackson and Lei Li for their contribution to the ES-MS instrumentation and William Clark, Jr., Gary J. Van Berkel, and Vilmos Kertesz for their valuable discussions. They also gratefully acknowledge Huiming Luo for the usage of the Karl Fischer titrator.

This research was sponsored by the Division of Chemical Sciences, Office of Basic Energy Sciences, U.S. Department of Energy. The submitted manuscript has been authored by a contractor of the U.S. Government under contract no. DE-AC0500OR22725 with Oak Ridge National Laboratory, managed and operated by UT-Battelle, LLC.

Accordingly, the U.S. Government retains a nonexclusive, royalty-free license to publish or reproduce the published form of this contribution, or allow others to do so, for U.S. Government purposes.

\section{References}

1. Zhang, H.; Hong, K.; Mays, J. W. Synthesis of Block Copolymers of Styrene and Methyl Methacrylate by Conventional Free Radical Polymerization in Room Temperature Ionic Liquids. Macromolecules 2002, 35, 5738-5741. 
2. Guerrero-Sanchez, C.; Ulrich, S. Polymer Synthesis in Ionic Liquids: Towards a Green Industry. Polym. Preprints (Am. Chem. Soc. Div. Polym. Chem.) 2004, 45, 321-322.

3. Muldoon, M. J.; Gordon, C. M. Synthesis of Gel-Type Polymer Beads from Ionic Liquid Monomers. J. Polym. Sci. A Polym. Chem. 2004, 42, 3865-3869.

4. Fei, Z.; Zhao, D.; Scoelliti, R.; Dyson, P. J. Organometallic Complexes Derived from Alkyne-Functionalized Imidazolium Salts. Organometallics 2004, 23, 1622-1628.

5. Mu, X.; Meng, J.; Li, Z.; Kou, Y. Rhodium Nanoparticles Stabilized by Ionic Copolymers in Ionic Liquids: Long Lifetime Nanocluster Catalysts for Benzene Hydrogenation. J. Am. Chem. Soc. 2005, 127, 9694-9695.

6. Schröder, U.; Wadhawan, J. D.; Compton, R. G.; Marken, F.; Suarez, P. A. Z.; Consorti, C. S.; F. de Souza, R.; Dupont, J. Water-induced Accelerated Ion Diffusion: Voltammetric Studies in 1-Methyl-3-[2, 6-(S)Dimethylocten-2-yl] Imidazolium Tetrafluoroborate, 1-Butyl-3-Methylimidazolium Tetrafluoroborate, and Hexafluorophosphate Ionic Liquids. New J. Chem. 2000, 24, 1009-1015.

7. Dai, S.; Ju, Y.; Barnes, C. Solvent Extraction of Strontium Nitrate by a Crown Ether Using Room-Temperature Ionic Liquids. J. Chem. Soc. Dalton Trans. 1999, 8, 1201-1201.

8. Santos, L. S. Haddad, R.; Höehr, N. F.; Pilli, R. A.; Eberlin, M. N. Fast Screening of Low Molecular Weight Compounds by Thin-Layer Chromatography and "On-Spot" MALDI-TOF Mass Spectrometry Anal. Chem. 2004, 76, 2144-2147.

9. Li, Y.: Gross, M. L.: Hsu, F. Ionic-Liquid Matrices for Improved Analysis of Phospholipids by MALDI-TOF Mass Spectrometry. J. Am. Soc. Mass Spectrom. 2005, 16, 679-682.

10. Zabet-Moghaddam, M.; Krueger, R.; Heinzle, E.; Tholey, A. MatrixAssisted Laser Desorption/Ionization Mass Spectrometry for the Characterization of Ionic Liquids and the Analysis of Amino Acids, Peptides, and Proteins in Ionic Liquids. J. Mass Spectrom. 2004, 39, 1494-1505.

11. Mank, M.; Stahl, B.; Boehm, G. 2, 5-Dihydroxybenzoic Acid Butylamine and Other Ionic Liquid Matrixes for Enhanced MALDI-MS Analysis of Biomolecules. Anal. Chem. 2004, 76, 2938-2950.

12. Carda-Broch, S.; Berthod, A.; Armstrong, D. W. Ionic Matrices for Matrix-Assisted Laser Desorption/Ionization Time-of-Flight Detection of DNA Oligomers. Rapid Commun. Mass Spectrom. (RCM) 2003, 17, $553-560$.

13. Armstrong, D. W.; Zhang, L. K.; He, L.; Gross, M. L. Ionic Liquids as Matrixes for Matrix-Assisted Laser Desorption/Ionization Mass Spectrometry. Anal. Chem. 2001, 73, 3679-3686.

14. Seddon, K. R.; Stark, A.; Torres, M. Influence of Chloride, Water, and Organic Solvents on the Physical Properties of Ionic Liquids. Pure Appl. Chem. 2000, 72, 2275-2287.
15. Fitchett, B. D.; Knepp, T. N.; Conboy, J. C. 1-Alkyl-3-Methylimidazolium bis(Perfluoroalkylsulfonyl)Imide Water-Immiscible Ionic Liquids. J. Electrochem. Soc. 2004, 151, E219-E225.

16. Welton, T. Room Temperature Ionic Liquids. Solvents for Synthesis and Catalysis. Chem. Rev. 1999, 99, 2071-2083.

17. Alfassi, Z. B.; Huie, R. E.; Milman, B.L.; Neta, P. Electrospray Ionization Mass Spectrometry of Ionic Liquids and Determination of Their Solubility in Water. Anal. Bioanal. Chem. 2003, 377, 159-164.

18. (a) Dyson, P. J.; McIndoe, J. S.; Zhao, D. Direct Analysis of Catalysts Immobilized in Ionic Liquids Using Electrospray Ionization Ion Trap Mass Spectrometry. Chem. Commun. 2003, 4, 508-509. (b) Zhao, D. Analysis of Ionic Liquids and Dissolved Species by Electrospray Ionization MS. Aust. J. Chem. 2004, 57, 509.

19. Jackson, G. P.; Duckworth, D. C. Electrospray Mass Spectrometry of Undiluted Ionic Liquids. Chem. Commun. 2004, 5, 522-523.

20. Lu, Y.; Duckworth, D. C.; Jackson, G. P.; King, F. L. Electrospray Mass Spectrometry of Room Temperature Ionic Liquids; PITTCON: Orlando, FL, 2005, No. 1340-21P.

21. Jones, R. M.; Gerlich, D.; Anderson, S. L. Simple Radio-Frequency Power Source for Ion Guides and Ion Traps. Rev. Sci. Instrum. 1997, 68, 3357-3362.

22. Fernandez de la Mora, J.; Van Berkel, G. J.; Enke, C. G.; Cole, R. B.; Martinez-Sanchez, M.; Fenn, J. B. Electrochemical Processes in Electrospray Ionization Mass Spectrometry. J. Mass Spectrom. 2000, 35, 939-952.

23. Van Berkel, G. J. Electrolytic Deposition of Metals on to the HighVoltage Contact in an Electrospray Emitter: Implications for Gas-Phase Ion Formation. J. Mass Spectrom. 2000, 35, 773-783.

24. Larson, J. W.; McMahon, T. B. Trends in Gas-Phase Fluoride Ion Affinities of Main-group Oxyfluorides and Fluoride Sulfides. Generation and Characterization of the Fluoride Adducts of $\mathrm{FAsO}, \mathrm{FPO}, \mathrm{FPO}_{2}$, $\mathrm{F}_{2} \mathrm{SiO}, \mathrm{F}_{4} \mathrm{SO}, \mathrm{FBO}, \mathrm{F}_{2} \mathrm{SiS}, \mathrm{FPS}, \mathrm{FAsS}, \mathrm{F}_{2} \mathrm{~S}_{2}$, and $\mathrm{S}_{2} \mathrm{O}$ by Ion Cyclotron Resonance Addition-Elimination Reactions. Inorg. Chem. 1987, 26, 40184023.

25. Christe, K. O.; Dixon, D. A.; Schrobilgen, G. J.; Wilson, W. W. Tetrafluorophosphate Anion. J. Am. Chem. Soc. 1997, 119, 3918-3928.

26. Kanevskii, L. S.; Dubasova, V. S. Degradation of Lithium-Ion Batteries and How to Fight It: A Review. Russ. J. Electrochem. 2005, 41, 1-16

27. Nagayama, K.; Kamioka, D.; Iwata, E.; Oka, H.; Tokunaga, Y.; Okada, T. The Reaction of Lithium-Manganese Oxides for the Cathode Materials of Rechargeable Lithium Batteries with Nonaqueous Electrolyte. Electrochemistry 2001, 69, 6-9.

28. Sloop, S. E.; Pugh, J. K.; Wang, S.; Kerr, J. B.; Kinoshita, K. Chemical Reactivity of $\mathrm{PF}_{5}$ and $\mathrm{LiPF}_{6}$ in Ethylene Carbonate/Dimethyl Carbonate Solutions. Electrochem. Solid-State Lett. 2001, 4, A42-A44. 